\title{
Influence of Albizia lebbeck Saponin and Its Fractions on In Vitro Gas Production Kinetics, Rumen Methanogenesis, and Rumen Fermentation Characteristics
}

\author{
Sunil Kumar Sirohi, ${ }^{1}$ Navneet Goel, ${ }^{1}$ and Nasib Singh ${ }^{1,2}$ \\ ${ }^{1}$ Dairy Cattle Nutrition Division, National Dairy Research Institute, Karnal, Haryana 132001, India \\ ${ }^{2}$ Lovely Professional University, Jalandhar, Punjab 144411, India \\ Correspondence should be addressed to Sunil Kumar Sirohi; sirohisk@gmail.com
}

Received 26 October 2013; Accepted 24 December 2013; Published 4 March 2014

Academic Editors: A. Paz Silva and W. Yang

Copyright (c) 2014 Sunil Kumar Sirohi et al. This is an open access article distributed under the Creative Commons Attribution License, which permits unrestricted use, distribution, and reproduction in any medium, provided the original work is properly cited.

\begin{abstract}
The present study was undertaken to investigate the effect of crude seed powder (CSP) and gross saponins extract (GSE) of seeds of Albizia lebbeck on antimicrobial activity by taking two Gram-positive (Staphylococcus aureus and Bacillus cereus), two Gramnegative (Escherichia coli and Salmonella Typhi) bacteria, and two fungi species (Aspergillus niger and Candida butyric) were taken at 25,50,100,250, and $500 \mu \mathrm{g}$ levels using agar well diffusion method. Zone of inhibition was increased with increasing of concentration of CSP and saponins which indicates that Gram-negative bacteria (E. coli), Gram-positive bacteria (B. cereus), and $A$. niger were significantly susceptible to inhibition. Another experiment was conducted to study the effect of GSE and saponins fraction $\mathrm{A}$ and $\mathrm{B}$ of $\mathrm{A}$. lebbeck supplementation at $6 \%$ on DM basis on methane production and other rumen fermentation parameters using in vitro gas production test, by taking three different type diets, that is, high fiber diet (D1, 60R : 40C), medium fiber diet (D2, 50R: 50C), and low fiber diet (D3, 40R:60C). Significant $(P \leq 0.05)$ increase was seen in IVDMD, methane production; however ammonia nitrogen concentration decreased as compared to control. The methane production was reduced in a range between 12 and $49 \%$ by saponin supplemented diets except in case of GSE in D2. Sap A showed the highest methane reduction per $200 \mathrm{mg}$ of truly digested substrate (TDS) than other treatment groups. Results in relation with quantification of methanogens and protozoa by qPCR indicated the decreasing trend with saponins of $A$. lebbek in comparison with control except total methanogen quantified using $m c r-A$ based primer.
\end{abstract}

\section{Introduction}

Methane production during anaerobic fermentation of nutrients in the rumen is an essential metabolic but nutritionally wasteful process which represents 2 to $15 \%$ of gross energy loss $[1,2]$. Livestock contributes $12-18 \%$ to the global anthropogenic greenhouse gas emissions depending upon emission attributes $[3,4]$ and accounts for about $37 \%$ of the total anthropogenic methane [3]. Therefore, reducing methane production is an important goal of ruminant nutritionists not only for reducing greenhouse gases and global warming but also for improving the efficiency of animal production. Recently, researchers have emphasized on the reduction of methane emission by using ionophores, organic acids, fatty acids, plant extracts, and halogenated methane analogues could be used to decrease ruminal methane production [5-12]. Plant secondary metabolites, that is, saponins, tannins, and essential oils have also been widely studied for their beneficial effect on ruminants and several workers reported that saponins and plants rich in saponins decreased the methane production in the rumen $[11,13-15]$. Hence, the present investigation was carried out to assess the effect of gross as well as pure saponins fraction of Albizia lebbeck on antimicrobial potential on selected bacterial and fungal pathogens, rumen fermentation characteristic, and antimethanogenesis. 


\section{Materials and Methods}

\subsection{Extraction, Isolation, and Estimation of Saponins}

2.1.1. Plant Materials. Seeds of Albizia lebbeck were collected from the campus of National Dairy Research Institute, Karnal, India. Seeds were washed with distilled water, dried at $50^{\circ} \mathrm{C}$ in hot air oven for $24 \mathrm{~h}$, then ground in hammer mill to pass through $1 \mathrm{~mm}$ sieve. The powder was stored in an airtight container until use.

2.1.2. Extraction and Isolation of Saponins. Seed powder was defatted in petroleum ether (boiling range $40-60^{\circ} \mathrm{C}$ ) refluxing for $6 \mathrm{~h}$ in a soxhlet's apparatus at $45^{\circ} \mathrm{C}$. The contents were filtered and $25 \mathrm{~g}$ fat-free sample was diluted with absolute methanol taken in 1:10 ratio. The contents were shaken at $25^{\circ} \mathrm{C}$ and $120 \mathrm{rpm}$ for $24 \mathrm{~h}$ followed by centrifuge for $20 \mathrm{~min}$ at $3500 \mathrm{rpm}$ for $20 \mathrm{~min}$. Methanol extract was filtered through Whatman filter paper Number 1 and dried under rotary evaporator. Dried methanolic plant extract was dissolved in distilled water $(10 \mathrm{~mL})$, transferred in to a separating funnel, and extracted with equal volume of $n$-butanol (3 times). Again, solvent, $n$-butanol was further evaporated at $45^{\circ} \mathrm{C}$. Dried saponins content was dissolved 5-10 mL of distilled water freeze dried resulting in a yellowish amorphous powder designated gross saponins extract (GSE).

Gross saponins extract (GSE) was extracted by previously described method [16]. GSE was fractionated by applying on silica gel (mesh range 60-120) column chromatography and eluted successfully with $\mathrm{CHCl}_{3}-\mathrm{MeOH}(9: 1)$ to yield fraction A; subsequent elution with $\mathrm{CHCl}_{3}-\mathrm{MeOH}-\mathrm{H}_{2} \mathrm{O}(40: 10: 1)$ to give the fraction $B$.

2.1.3. Estimation of Total Saponins. Total saponins contents of $A$. lebbeck seeds were estimated by colorimetric methods [17]. Gross saponins extract $(10 \mathrm{mg})$ was dissolved in $5 \mathrm{~mL}$ of $80 \%$ aqueous methanol and $50 \mu \mathrm{L}$ of this solution was taken in different test tubes to which $0.25 \mathrm{~mL}$ of vanillin reagent $(8 \%, \mathrm{w} / \mathrm{v}$ in $99.9 \%$ ethanol) was added. Test tubes were placed in ice-cold water bath and $2.5 \mathrm{~mL}$ of $72 \%(\mathrm{v} / \mathrm{v})$ sulphuric acid was added slowly on the inner side of the wall. After mixing the content in each tube, then left as such for $3 \mathrm{~min}$, then warmed the tubes at $60^{\circ} \mathrm{C}$ for $10 \mathrm{~min}$ using water bath and cooled in ice-cold water bath. Absorbance was measured at $544 \mathrm{~nm}$ using spectrophotometer against the reagent blank and standard curve was prepared. Quillaja saponin (Sigma-Aldrich) was used as a reference standard [18] and the concentration of total saponins was expressed as Quillaja saponin equivalents (QS $\mu \mathrm{g} / \mathrm{mg}$ extract).

\subsection{Antimicrobial Study (Experiment 1)}

2.2.1. Microbial Cultures. Two Gram-positive and two Gramnegative bacteria and two fungi species were employed to determine the antimicrobial action of $A$. lebbeck seed powder extracted saponins. All microbial cultures were taken from National Collection Centre, Dairy Microbiology Division, National Dairy Research Institute, Karnal, India, and
Microbial Type Culture Collection, IMTECH, Chandigarh, India.

2.2.2. Antimicrobial Activity Assay. Antibacterial and antifungal activities of the crude seed powder (CSP) and gross saponins extract (GSE) were tested using agar well diffusion method as described previously [19]. Nutrient agar/BHI agar was used for the determination of antibacterial and antifungal activities. The samples were tested at 25, 50, 100,250 , and $500 \mu \mathrm{g}$ concentrations of treatments. On agar plates test bacterial cultures $\left(10^{8} \mathrm{cfu} / \mathrm{mL}\right)$ were spread with sterilized loop and incubated at $37^{\circ} \mathrm{C}$ for $3 \mathrm{~h}$. Wells of $8 \mathrm{~mm}$ size were punched on plates using sterile borer. Different dilutions of test samples were then added to the wells in approximately $100 \mu \mathrm{L}$ volume. Following incubation for $24-48 \mathrm{~h}$ at $37^{\circ} \mathrm{C}$, the sensitivity of the bacterial species to the saponins was determined by measuring the diameter of the zone of inhibition around the well. Each sample was assayed in triplicate. Chloramphenicol ( $30 \mu \mathrm{g} / \mathrm{well})$ and Kanamycin sulphate (50 $\mu \mathrm{g} /$ well) were used as possible control for Gram-positive bacteria and Gram-negative bacteria, respectively.

Suspensions of fungal spores were prepared from 5-7 days old cultures that grew at $28^{\circ} \mathrm{C}$ on a SDA plates which were prepared by pour plating using fungal spores of $A$. niger as inoculums. An aliquot to this inoculum was introduced to molten SDA and poured into petri dishes. C. butyri agar plates were also prepared by pour plating. Wells of 8 diameters were punched and test samples were introduced at different concentration as described in the previous section. Plates were incubated for $24-48 \mathrm{~h}$ at $28^{\circ} \mathrm{C}$ for $A$. niger and at $35^{\circ} \mathrm{C}$ for $C$. butyri. The antifungal activity was evaluated by measuring zones of inhibition of fungal growth surrounding the wells. Each sample was assayed in triplicate and Nystatin $(50 \mu \mathrm{g} /$ well $)$ was used as positive control.

\subsection{In Vitro Rumen Fermentation (Experiment 2)}

2.3.1. Diets. The substrates used in incubation were prepared by taking different roughage and concentrate ratio, that is, high fiber diet $\left(D_{1}, 60 R: 40 C\right)$, medium fiber diet $\left(D_{2}\right.$, 50R:50C), and low fiber diet ( $\left.\mathrm{D}_{3}, 40 \mathrm{R}: 60 \mathrm{C}\right)$ and milled to pass through $1 \mathrm{~mm}$ sieve and used as substrate. The roughage part composed of wheat straw and the concentrate part composed of maize (33\%), GNC (21\%), mustard cake (12\%), wheat bran (20\%), deoiled rice bran (11\%), mineral mixture $(2 \%)$, and common salt (1\%), respectively.

2.3.2. Experimental Design and Technique. All the treatments, that is, $6 \%$ (DM basis) of gross saponins extract (GSE) and saponin fractions $A$ and $B$ were arranged in factorial randomized block design (RBD) with three replicates. Sets were also incubated devoid of substrate with and without supplementation which served as blanks for particular treatment and values were corrected for different parameters with blanks. The experiment was conducted in $100 \mathrm{~mL}$ calibrated glass syringes containing $200 \pm 5 \mathrm{mg}$ of substrates with $6 \%$ GSE and $6 \%$ of saponins fraction $\mathrm{A}$ and $\mathrm{B}$, respectively, and 
then $30 \mathrm{~mL}$ reduced buffer medium [20] was anaerobically added to each syringe. Syringes were incubated at $39^{\circ} \mathrm{C}$ for $48 \mathrm{~h}$ in temperature-controlled water bath cum shaker. The rumen liquor was from a fistulated adult male buffalo (Bubalus bubalis) maintained on a standard diet (roughage: concentrate; $60: 40) 1 \mathrm{~h}$ before morning feed. Strained rumen liquor was collected in sterile, prewarmed and pre- $\mathrm{CO}_{2}$ flushed insulated thermos flask and brought to the laboratory immediately. All animal procedures were performed in accordance with the guidelines of Institutional Animal Ethics Committee of National Dairy Research Institute, Karnal (India).

\subsubsection{In Vitro Total Gas (TG) Production and Methane Esti-} mation. After $48 \mathrm{~h}$ incubation, total gas (TG) was estimated by the extent of displacement of piston of glass syringes. TG produced due to fermentation of substrate was corrected by subtracting TG produced in blank syringe (containing inoculum and buffer but not the substrate) from total gas produced in the syringe containing substrate, inoculum, and buffer. Methane concentration in representative gas samples was estimated by using gas chromatograph (Nucon-5765, India) equipped with flame ionization detector (FID) and stainless steel column packed with Porapak-Q (length $6^{\prime}$; o.d.1/8" i. d. $2 \mathrm{~mm}$; mesh range $80-100$ ). The gas flow rates for nitrogen, hydrogen, and air were 30,30 , and $300 \mathrm{~mL} / \mathrm{min}$, respectively. Temperature of injector oven, column oven, and detector were 40,50 , and $50^{\circ} \mathrm{C}$, respectively. $\mathrm{CH}_{4}$ in samples were calculated by external calibration, using a certified gas standard mixture of $50 \% \mathrm{CH}_{4}$ and $50 \% \mathrm{CO}_{2}$ (Spantech, England).

\subsubsection{Measurements of Digestibility and Fermentation Param-} eters. The true DM degradability of feed sample of each syringe containing residues after incubation was estimated as per method [21]. The proximate analysis (organic matter, crude protein, ether extract, and total Ash) of substrate was carried out as per the method [22]. The cell wall constituents of substrates were determined according to described method [23]. For determination of $\mathrm{NH}_{3}-\mathrm{N}, 5 \mathrm{~mL}$ of supernatant was taken in tube mixed with $12 \mathrm{~mL} 1 \mathrm{~N} \mathrm{NaOH}$ and steam passed using KEL PLUS-N analyzer (Pelican, India) and the $\mathrm{NH}_{3}$ evolved was collected in conical flask containing boric acid solution having mixed indicator and titrated against N/100 $\mathrm{H}_{2} \mathrm{SO}_{4}$.

For the estimation of individual volatile fatty acids, $4 \mathrm{~mL}$ of $25 \%$ metaphosphoric acid was added to $1 \mathrm{~mL}$ of incubation sample; the mixture was mixed uniformly and left as such for 3-4 $\mathrm{h}$ at ambient temperature [24]. Thereafter, samples were centrifuged at $3000 \mathrm{rpm}$ for $10 \mathrm{~min}$ and clear supernatant was stored at $-20^{\circ} \mathrm{C}$ until analyzed. The volatile fatty acids were analyzed by using gas liquid chromatography (Nucon-5765, New Delhi, India) after some modification of the previously described method [6].

2.3.5. Estimation of Partition Factor (PF) and Microbial Biomass Production (MBM). The PF is calculated as the ratio of substrate truly degraded in vitro $(\mathrm{mg})$ to the volume of gas $(\mathrm{mL})$ produced by it. Substrate provides important information about partitioning of fermentation products. The MBM yield was calculated by using the degradability of substrate and gas volume and stoichiometrical factor as suggested [25]:

$$
\begin{aligned}
\text { Microbial mass }= & \text { Substrate truly degraded } \\
& -(\text { gas volume } \\
& \quad \times \text { stoichiometrical factor }),
\end{aligned}
$$

where the stoichiometrical factor used was 2.25.

2.3.6. Quantitative Real-Time PCR ( $q$ RT-PCR) Quantification of Methanogens. Content of the glass syringes containing $\mathrm{D}_{2}$ with treatment was shaken thoroughly and one $\mathrm{mL}$ samples was withdrawn at $48 \mathrm{~h}$ of the experiment. Total genomic DNA was extracted using genomic DNA extraction kit (Fermentas, USA) as per manufacturer's instructions. DNA concentrations were measured in NanoQuant instrument (Tecan, USA). In order to minimize the variations, DNA was extracted from all three samples. qRT-PCR was performed to quantify total rumen methanogens, methanomicrobiales, and protozoa. Assays were performed in MJ Mini Mini Opticon Real-Time PCR System (Bio-Rad, USA) using SYBR Green Jump Start Taq Readymix (Sigma, USA). The primer pairs used for different microbial groups are described in Table 5. Samples were assayed in $25 \mu \mathrm{L}$ reaction mixture containing $5 \mathrm{mM} \mathrm{MgCl}$, SYBR Green master mix, $50 \mathrm{ng}$ of template DNA, and $0.5 \mu \mathrm{M}$ of each primer. All assays were performed in triplicate.

2.3.7. Gas Production Kinetics. The total gas production kinetics and cumulative methane gas production were carried out in $\mathrm{D}_{2}$ with different treatment combinations and incubated as per the procedure mentioned above for different intervals, that is, $0,1,2,3,6,9,12,24,36,48,60,72$, and $96 \mathrm{~h}$. Kinetics of gas production was calculated using a nonlinear model [26]. The NLIN procedure of Sigma stat 3.11 was used to fit the following model: $p=b\left[1^{-e-c(t)}\right]$, where $p$ is the gas production rate at time $t, b$ is the potential gas production $(\mathrm{mL})$, and $c$ is gas production rate constant $(\mathrm{mL} / \mathrm{h})$ of $b$ and $t$ is the time of incubation (h). The potential gas production and rate of gas production were calculated by fitting the modified equation [26].

2.4. Statistical Analysis. Experimental data of different parameters were analyzed in randomized block design with three replicates for analysis of variance [27]. The effects of gross saponins and different saponins fraction compared with controls were tested using the factorial arrangement in randomized block design in OPSTAT (http://14.139.232.166/opstat/index.asp) statistical software developed by Chaudhry Charan Singh, Haryana Agriculture University, Hissar, Haryana, India [28]. 
TABLE 1: In vitro antibacterial and antifungal activities (zone of inhibition in $\mathrm{mm}$ ) of $A$. lebback treatments using agar well diffusion method.

\begin{tabular}{|c|c|c|c|c|c|c|c|c|c|c|c|c|c|}
\hline \multirow{3}{*}{ Types } & \multirow{3}{*}{ Names } & \multirow{3}{*}{$\begin{array}{l}\text { Specimen } \\
\text { number }\end{array}$} & \multicolumn{5}{|c|}{ Zone of inhibition (CSP) } & \multicolumn{5}{|c|}{ Zone of inhibition (GSE) } & \multirow{3}{*}{ Positive control } \\
\hline & & & \multicolumn{10}{|c|}{ Concentration $(\mu \mathrm{g})$} & \\
\hline & & & 500 & 250 & 100 & 50 & 25 & 500 & 250 & 100 & 50 & 25 & \\
\hline \multirow{2}{*}{ Gram-negative bacteria } & Escherichia coli & NCDC 135 & 7.2 & 4.8 & 3.3 & 1.3 & $\mathrm{nz}$ & 12.8 & 8.9 & 7.3 & 4.0 & 1.9 & $17.7^{\mathrm{a}}$ \\
\hline & Salmonella Typhi & NCDC 113 & 3.9 & 2.6 & 1.1 & $\mathrm{nz}$ & $\mathrm{nz}$ & 9.2 & 5.9 & 5.7 & 2.8 & $\mathrm{nz}$ & $14.7^{\mathrm{a}}$ \\
\hline \multirow{2}{*}{ Gram-positive bacteria } & Staphylococcus aureus & MTCC 1144 & 3.4 & 2.1 & 0.9 & $\mathrm{nz}$ & $\mathrm{nz}$ & 7.4 & 6.2 & 5.0 & 2.3 & $\mathrm{nz}$ & $9.3^{\mathrm{b}}$ \\
\hline & Bacillus cereus & NCDC 240 & 7.8 & 4.4 & 2.3 & 1.8 & $\mathrm{nz}$ & 13.3 & 10.1 & 6.3 & 3.3 & 2.0 & $16.7^{\mathrm{b}}$ \\
\hline \multirow{2}{*}{ Fungi } & Candida butyri & NCDC 280 & 0.8 & $\mathrm{nz}$ & $\mathrm{nz}$ & $\mathrm{nz}$ & $\mathrm{nz}$ & 3.2 & 1.2 & $\mathrm{nz}$ & $\mathrm{nz}$ & $\mathrm{nz}$ & $6.0^{c}$ \\
\hline & Aspergillus niger & NCDC 315 & 6.7 & 4.3 & 1.0 & $\mathrm{nz}$ & $\mathrm{nz}$ & 11.8 & 8.5 & 3.0 & 1.4 & $\mathrm{nz}$ & $13.2^{\mathrm{c}}$ \\
\hline
\end{tabular}

Sterile broth medium as negative control.

${ }^{\mathrm{a}}$ Kanamycin sulphate $(50 \mu \mathrm{g} / \mathrm{well})$.

${ }^{\mathrm{b}}$ Chloramphenicol $(30 \mu \mathrm{g} /$ well $)$.

${ }^{\mathrm{c}}$ Nystatin $(50 \mu \mathrm{g} /$ well $)$.

Nz: No zone.

\section{Results and Discussion}

3.1. Antimicrobial Activity. The crude seed powder (CSP) and gross saponins extract (GSE) of A. lebbeck seed exhibited significant antimicrobial activities against bacterial and fungal cultures (Table 1). The extent of inhibition was greater in the case of pure saponin fraction than crude saponins fractions.

The results of present experiments indicated that the zones of inhibition for Gram-negative and Gram-positive bacteria were increased with increasing of concentration of treatments, that is, CSP and GSE. Gram-negative bacteria $E$. coli and Gram-positive bacteria B. cereus were more susceptible to inhibition than other tested bacteria to CSP and GSE. E. coli showed the maximum zone of inhibition $(12.8 \mathrm{~mm}$, $7.2 \mathrm{~mm}$ ), while, $B$. cereus showed the maximum $(13.3 \mathrm{~mm}$, $7.8 \mathrm{~mm}$ ) at $500 \mu \mathrm{g}$ levels of GSE and CSP, respectively. Grampositive bacteria $B$. cereus was more susceptible to inhibition in comparison with Gram-negative bacteria E. coli. GSP and GSE were also used for the evaluation of their antifungal activity against Candida butyri and Aspergillus niger. A. niger was significantly susceptible to inhibition by saponins fraction and showed the highest inhibition 11.8 and $6.7 \mathrm{~mm}$ at $500 \mu \mathrm{g}$ level of GSE and CSP, respectively. C. butyri was least inhibited by saponin fractions and showed the highest inhibition ( $3.2 \mathrm{~mm}$ ) at $500 \mu \mathrm{g}$ level of GSE and did not showed any activity at low level of GSE as well as CSP. The results of present study indicated that gross saponins fraction of $A$. lebbeck showed the inhibitory action against Garm-positive bacteria but not show significant inhibition against Gramnegative bacteria and fungi. This is not surprising because the Gram-negative bacteria and fungi have been shown to be more resistant to antibiotics $[29,30]$. This may possibly be the presence of high lipid content in the cell walls of Gramnegative bacteria and saponins may not be able to penetrate the cell membrane of the microorganism $[31,32]$. The finding of present study was consistent with previous published reports that specifically showed that saponins could have antimicrobial properties [33-35].
TABLE 2: Chemical composition of diets.

\begin{tabular}{lccc}
\hline Diets & \multicolumn{3}{c}{ Chemical constituents of diets $(\mathrm{g} / \mathrm{kg}$ on DM basis $)$} \\
& $\left(\mathrm{D}_{1}\right)(60 R: 40 \mathrm{C})$ & $\left(\mathrm{D}_{2}\right)(50 R: 50 \mathrm{C})$ & $\left(\mathrm{D}_{3}\right)(40 R: 60 \mathrm{C})$ \\
\hline $\mathrm{OM}$ & 867.6 & 878.4 & 875.6 \\
$\mathrm{CP}$ & 108.6 & 125.3 & 142.7 \\
$\mathrm{EE}$ & 23.4 & 30.4 & 34.8 \\
$\mathrm{NDF}$ & 623.1 & 604.5 & 538.7 \\
$\mathrm{ADF}$ & 372.0 & 329.5 & 298.7 \\
$\mathrm{HC}$ & 251.1 & 275.0 & 240.0 \\
TA & 132.4 & 121.6 & 124.4 \\
\hline
\end{tabular}

$\mathrm{D}_{1}$ : high fiber diet, $\mathrm{D}_{2}$ : medium fiber diet, $\mathrm{D}_{3}$ : low fiber diet, OM: organic matter, CP: crude protein, EE: ether extract, NDF: neutral detergent fiber, ADF: acid detergent fiber, HC: hemicelluloses, TA: total Ash.

3.2. In Vitro Dry Matter Digestibility (IVDMD) and Rumen Fermentation Parameters. The ingredient and chemical compositions of diets containing different roughage and concentration ratio were presented in Table 2 . In vitro results of incubating three diets during $48 \mathrm{~h}$ with GSE, saponin fraction A and $\mathrm{B}$ on digestibility, rumen fermentation, methanogenesis, and so forth were presented in Tables 3 and 4, respectively.

3.2.1. IVDMD, Partition Factor and Microbial Biomass. In the current experiment, results indicated that IVDMD values were increased as compared to control and the differences among treatments values were significant $(P \leq 0.05)$ except GSE inclusion in $\mathrm{D}_{2}$ and $\mathrm{D}_{3}$, where slight reduction in IVDMD was observed. In case of $\mathrm{D}_{1}$ and $\mathrm{D}_{3}$, IVDMD was increased with $15.33 \%$ and $2.05 \%$ by supplementation of saponin fractions $\mathrm{A}$, while in $\mathrm{D}_{2}$ highest $7.38 \%$ increase of IVDMD was noticed on inclusion of saponin fraction $B$ of A. lebbeck seeds. Digestibility increase as a result of the presence of saponins was similar to the previous studies [36], in which the apparent dry matter digestibility increased on supplementation of surfactant saponins at the levels of 5$20 \mu \mathrm{L} / \mathrm{g}$ dry matter. Another study reported that the IVDMD 


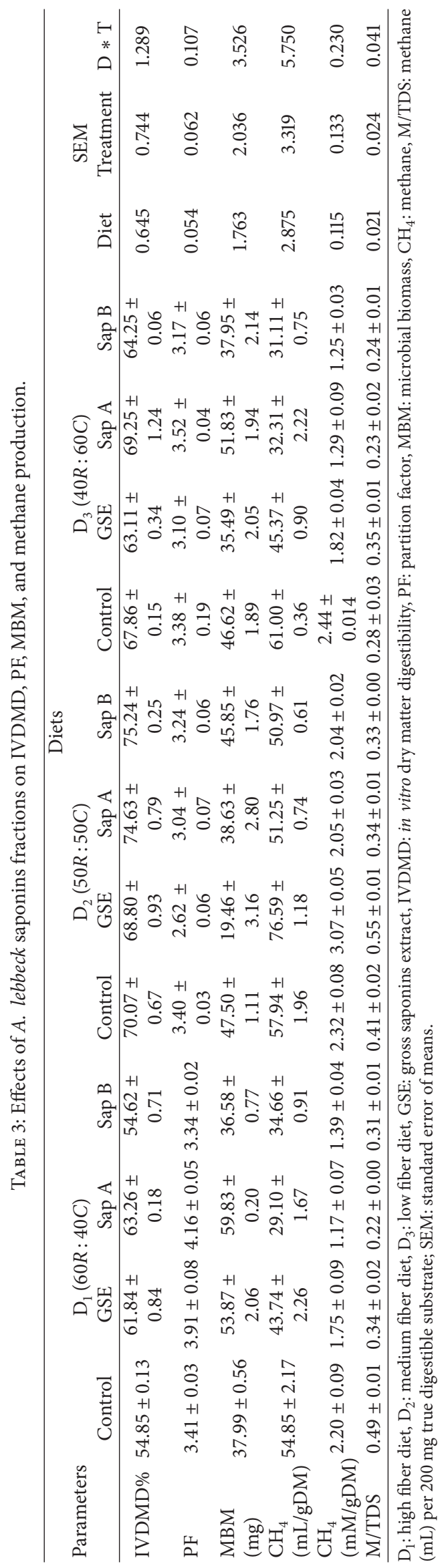




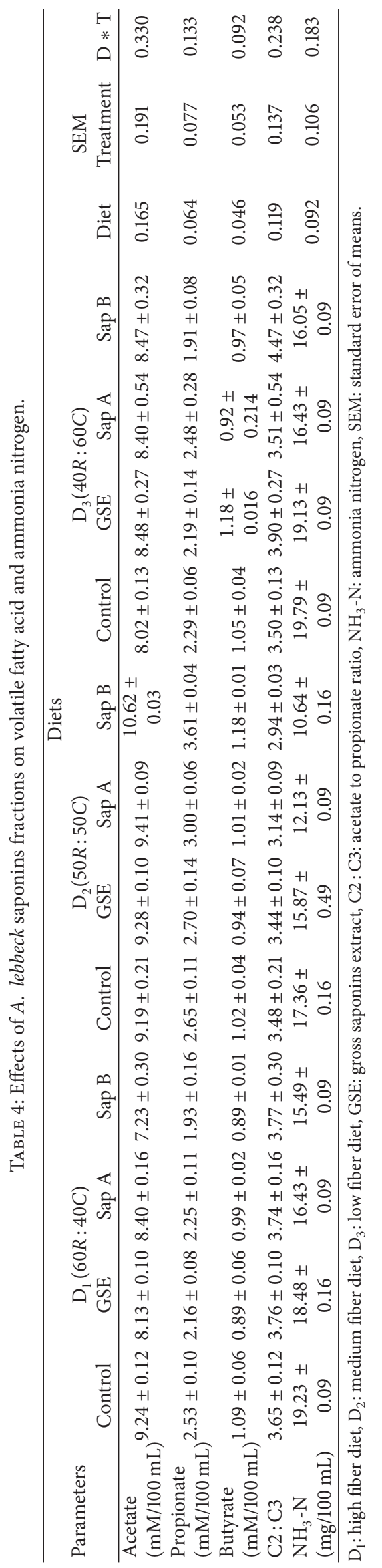


was not affected significantly $(P<0.05)$ on the addition of pure saponins [37].

In present study the partition factor $(\mathrm{PF})$ values and microbial biomass (mg) production decreased with all saponins supplementation in $\mathrm{D}_{2}$ and $\mathrm{D}_{3}$; however, in $\mathrm{D}_{1}$, 21.99\% and 55.92\% increases in PF and MBM were observed during supplementation of saponins fraction A (Table 3). This finding was in accordance with the finding of Goel et al. [38]. They reported that the MBM and PF increased on inclusion with extracted saponins from Achyranthes aspera, Tribulus terrestris, and Albizia lebbeck at 3, 6, and 9\% levels on DM basis.

3.2.2. Methane Production. Results of present study indicated that methane production was decreased in saponins extracted from $A$. lebbeck seed supplementation and in different diets; methane production ( $\mathrm{mL} / \mathrm{gDM})$ was reduced approximately in the range 12 to $49 \%$, except GSE with $\mathrm{D}_{2}$. Results of current study showed that the methane production was reduced up to $49 \%$ which was in accordance with results of several experiments conducted by different workers [14, 39-41]. In another study, Holtshausen et al. [42] reported in study with Yucca schidigera plant extract containing 6\% saponins which showed $8.5 \%$ methane reduction at the level of $0.38 \mathrm{~g} /$ liter. Similarly, Feng et al. [43] showed that gross saponin of Tribulus terrestris at $0.3,0.6$, and $0.9 \mathrm{~g} /$ liter levels significantly $(P<0.05)$ reduced methane concentration by $23.43,24.93$, and $25.30 \%$, respectively, by in vitro gas production technique.

Results of the present experiment showed that the reduction of methane production per $200 \mathrm{mg}$ of truly digested substrate (TDS) was highest in saponin fraction A with all diets, when compared with control (Table 3). These results were in agreement with the earlier finding. CastroMontoya et al. [44] showed that addition of Quillaja saponin reduced the methane by $4.1 \mathrm{~mL} / 100 \mathrm{mg}$ substrate at $1.25 \mathrm{mg}$ of saponin/liter under in vitro studies.

In the rumen, the methane production also depends upon the association between methanogens, protozoa, and rate of methane production per methanogenic cell [45]. Patra and Saxena [15] suggested that saponin may decrease the protozoal numbers which leads to reducing the availability of hydrogen ions for methane production by methanogens. Furthermore, it has been shown that the saponins reduced methane production via diminished activity of methane producing gene without changing the total methanogen population [41].

\subsubsection{Short Chain Fatty Acid (SCFA) and Ammonia Nitrogen.} The individual volatile fatty acids (IVFAs) concentration varied among the treatments (Table 4). Acetate concentration increased on inclusion of all treatments in case of $\mathrm{D}_{2}$ and $\mathrm{D}_{3}$ and highest increased (15.66\%) was seen in saponin fraction B supplementation in $\mathrm{D}_{2}$. While in $\mathrm{D}_{1}$, acetate production was decreased in all treatments.

Results of current experiment indicated that the concentration of propionate slightly was affected by A. lebbeck seed saponins. In $\mathrm{D}_{2}$, it was increased in all treatments and
TABLE 5: Effects of A. lebbeck saponins fractions on total gas potential (96h) using $\mathrm{D}_{2}$ as a substrate.

\begin{tabular}{lccc}
\hline & \multicolumn{2}{c}{ Equation: $A=b^{X}\left(1-\exp \left(-c^{X} x\right)\right)$} & \\
& $b$ & $c$ & $R^{2}$ \\
\hline Control & $186.35 \pm 5.07$ & $0.215 \pm 0.015$ & 0.993 \\
GSE & $220.14 \pm 8.10$ & $0.195 \pm 0.015$ & 0.989 \\
Sap A & $175.69 \pm 8.17$ & $0.181 \pm 0.020$ & 0.986 \\
Sap B & $209.03 \pm 8.44$ & $0.191 \pm 0.195$ & 0.988 \\
\hline
\end{tabular}

GSE: gross saponins extract, $b$ : potential gas production $(\mathrm{mL}) ; c$ : gas production rate constant $(\mathrm{mL} / \mathrm{h}), R^{2}$ : regression coefficient.

TABLE 6: Effects of A. lebbeck saponins fractions on methane gas potential ( $96 \mathrm{~h}$ ) using $\mathrm{D}_{2}$ as a substrate.

\begin{tabular}{lccc}
\hline & Equation: $A=b^{X}\left(1-\exp \left(-c^{X} x\right)\right)$ & \\
& $b$ & $c$ & $R^{2}$ \\
\hline Control & $55.865 \pm 1.82$ & $0.192 \pm 0.015$ & 0.992 \\
GSE & $67.24 \pm 3.61$ & $0.174 \pm 0.02$ & 0.982 \\
Sap A & $53.54 \pm 3.28$ & $0.166 \pm 0.02$ & 0.979 \\
Sap B & $61.14 \pm 3.50$ & $0.169 \pm 0.02$ & 0.981 \\
\hline
\end{tabular}

GSE: gross saponins extract, $b$ : potential methane gas production $(\mathrm{mL}) ; c$ : methane production rate constant $(\mathrm{mL} / \mathrm{h}), R^{2}$ : regression coefficient.

increased most with saponins fraction B (36.23\%) in comparison to control (Table 4). Nonsignificant change in butyrate concentrations were observed in present study. Among all three diets, only $\mathrm{D}_{2}$ showed the slight decrease in $\mathrm{A} / \mathrm{P}$ ratio; however, in case of $\mathrm{D}_{1}$ and $\mathrm{D}_{2}$ it was increased and highest increase $(27.71 \%)$ was seen in $\mathrm{D}_{3}$ on supplementation with saponin fraction $\mathrm{B}$. The results of present study were in accordance with several other studies $[13,46]$. In another study, Istiqomah et al. [47] observed that the acetate to propionate ratio decreased at 5, 10, and $15 \%$ saponin levels. Similarly, Feng et al. [43] also observed that the saponin level at $0.9 \mathrm{~g} / \mathrm{L}$ decreased the acetic acid and at 0.6 and $0.9 \mathrm{~g} / \mathrm{L}$ increased the propionic acid concentration significantly when compared to the control.

The ammonia nitrogen $(\mathrm{mg} / 100 \mathrm{~mL})$ was decreased due to the $A$. lebbeck seed saponins in all three diets, and the maximum decrease $\left(38.71 \%\right.$ ) was found in $\mathrm{D}_{3}$ on supplementation with saponin fraction $B$ (Table 4 ). The results of current study indicated that the ammonia nitrogen was marginally affected and slightly decreased as compared to control diet without supplementation of saponins. Results were consistent with earlier reports [37, 43, 48]. Bharathidhasan et al. [37] observed that nonsignificant reduction in ammonia nitrogen on inclusion with purified saponins at the levels of $0,1.55,3.10$, 4.65 and $6.20 \mathrm{mg} / 30 \mathrm{~mL}$ rumen inoculums.

3.2.4. Gas Kinetics of Total Gas and Methane Production. Results related to gas kinetics in $\mathrm{D}_{2}$ diet are presented in Table 5. Gas kinetics results showed that potential gas production (b) was increased on supplementation with GSE (18.13\%) and saponin fraction B (12.17\%), while slight decrease was noticed on saponin fraction A inclusion in comparison to control (Figure 1). On the other hand, the gas 
TABLE 7: Real-time PCR quantification of changes in rumen microbial population on supplementation of $A$. lebbeck (saponins fractions).

\begin{tabular}{|c|c|c|c|c|c|c|}
\hline Microbial groups & Control diet $\left(\mathrm{D}_{2}\right)$ & $\mathrm{D}_{2}+\mathrm{GSE}$ & $\mathrm{D} 2+$ Sap A & $\mathrm{D}_{2}+$ Sap B & SEM & $\mathrm{CD}$ \\
\hline MMB & 1.00 & 0.318 & 0.484 & 1.581 & 0.091 & 0.321 \\
\hline Protozoa & 1.00 & 0.940 & 0.649 & 0.985 & 0.070 & 0.247 \\
\hline mcrA & 1.00 & 0.584 & 3.198 & 3.392 & 0.881 & N.S. \\
\hline
\end{tabular}

MMB: methanomicrobiales; mcr A: total methanogens quantified using mcr A gene; in control diet population of all microbes considered as 1.00 then relative abundance is calculated with treatment.

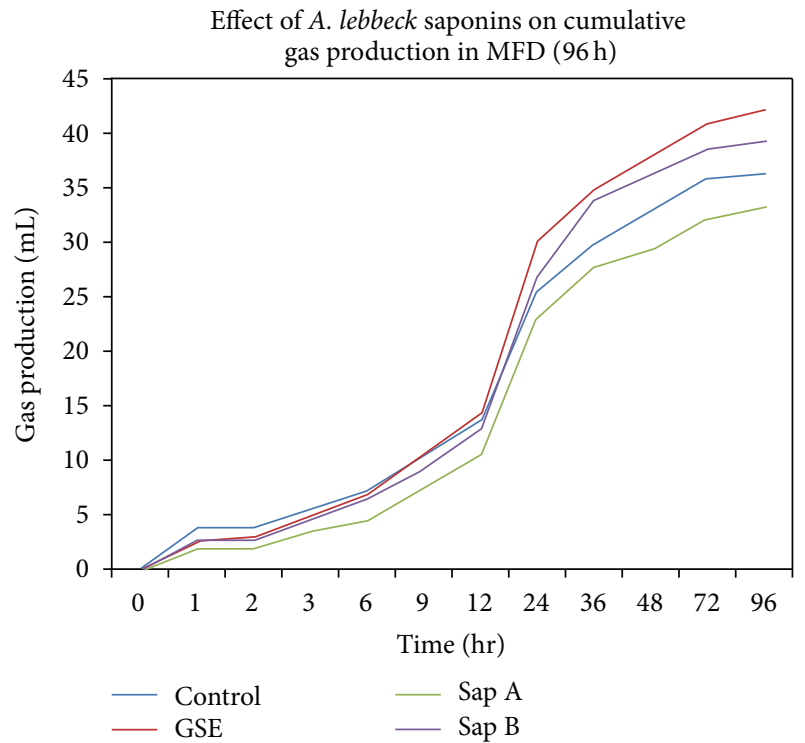

Figure 1: Effects of A. lebbeck saponins fractions on total gas potential ( $96 \mathrm{~h})$ using $\mathrm{D}_{2}$ as a substrate.

production rate (c) was decreased in all treatments and highest decrease $(15.81 \%)$ was noticed on inclusion of saponin fraction $\mathrm{A}$ in diets.

In current study, the results of cumulative methane gas production $(\mathrm{mL} / \mathrm{gDM})$ were presented in Table 6 and trends were similar to gas kinetics. Highest $(20.35 \%)$ increase in methane gas potential (b) and highest reduction (13.54\%) in methane production rate were observed on supplementation with GSE and saponin fraction A, respectively (Figure 2).

\subsubsection{Quantification of Methanogens and Protozoal Popula-} tion. In present study, results of quantification of methanogens and protozoal population are presented in Table 7. Results indicated that all treatments show the antiprotozoal effect and maximum reduction in protozoa population (35.1\%) was seen in saponin fraction A, when compared to control diet. The results of present experiment were consistent with earlier studies $[14,49,50]$. It is believed that saponins form complexes with cholesterol present in the cell membrane and result in the cell lysis, which in turn decreases the hydrogen ion transfer and ultimately reduces the methane production [51].

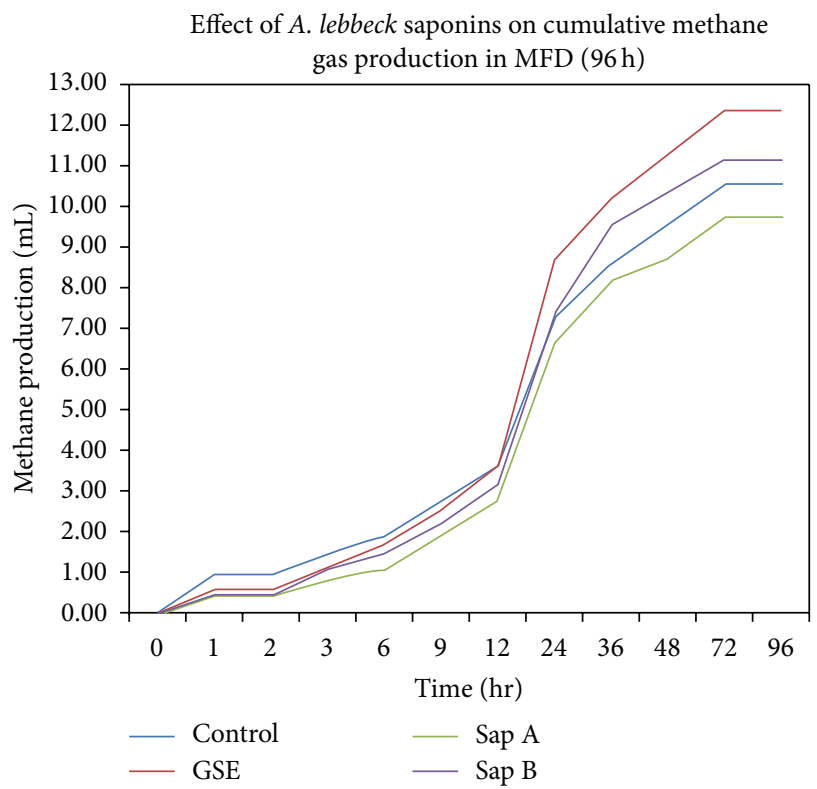

FIgURE 2: Effects of $A$. lebbeck saponins fractions on methane gas potential ( $96 \mathrm{~h}$ ) using $\mathrm{D}_{2}$ as a substrate.

\section{Conclusions}

In present study it is concluded that saponins fraction $\mathrm{A}$ of Albizia lebbeck has antimethanogenic potential and has an ability to modulate the rumen fermentation parameters. However, a systematic evaluation is needed to confirm the active structural components of saponin fraction $\mathrm{A}$, and their interaction with the microbial community and the diet, and to clarify the mechanism by which saponin fraction A or their metabolites exert effects on the rumen microbes.

\section{Conflict of Interests}

The authors declare that there is no conflict of interests regarding the publication of this paper.

\section{Acknowledgments}

Authors are thankful to National Fund for Basic and Strategic Research in Agriculture (NFBSRA), Indian Council of Agricultural Research (ICAR), New Delhi, for provide the financial support under Grant F. no. NFBSRA/PCN/AP10/2006-07 to carry out this research work. 


\section{References}

[1] A. R. Moss, J. Jouany, and J. Newbold, "Methane production by ruminants: its contribution to global warming," Animal Research, vol. 49, no. 3, pp. 231-253, 2000.

[2] K. A. Johnson and D. E. Johnson, "Methane emissions from cattle," Journal of Animal Science, vol. 73, no. 8, pp. 2483-2492, 1995.

[3] FAO, Livestock's Long Shadow. Environmental Issues and Options, Food and Agriculture Organization of the United Nations, Rome, Italy, 2006.

[4] H. Westhoek, T. Rood, M. van den Berg et al., The Protein Puzzle, PBL Netherlands Environmental Assessment Agency, The Hague, The Netherlands, 2011.

[5] S. A. Martin, "Manipulation of ruminal fermentation with organic acids: a review," Journal of Animal Science, vol. 76, no. 12, pp. 3123-3132, 1998.

[6] S. K. Sirohi, P. Pandey, and N. Goel, Response of Fumaric Acid Addition on Ethanogenesis, Rumen Fermentation and Dry Matter Degradability in Diets Containing Wheat Straw and Sorghum or Berseem as Roughage Source, Veterinary Science, 2012.

[7] F. Dohme, A. Machmüller, A. Wasserfallen, and M. Kreuzer, "Ruminal methanogenesis as influenced by individual fatty acids supplemented to complete ruminant diets," Letters in Applied Microbiology, vol. 32, no. 1, pp. 47-51, 2001.

[8] M. Busquet, S. Calsamiglia, A. Ferret, and C. Kamel, "Screening for effects of plant extracts and active compounds of plants on dairy cattle rumen microbial fermentation in a continuous culture system," Animal Feed Science and Technology, vol. 123124, pp. 597-613, 2005.

[9] N. W. Tomkins and R. A. Hunter, "Methane mitigation in beef cattle using a patented antimethanogen," in Proceedings of the 2nd Joint Australia and New Zealand Forum on Non-CO2 Greenhouse Gas Emission from Agriculture, R. Eckard, Ed., CRC for Greenhouse Accounting, 2003.

[10] N. J. Choi, S. Y. Lee, H. G. Sung, S. C. Lee, and J. K. Ha, "Effects of halogenated compounds, organic acids and unsaturated fatty acids on in vitro methane production and fermentation characteristics," Asian-Australasian Journal of Animal Sciences, vol. 17, no. 9, pp. 1255-1259, 2004.

[11] R. Bodes, N. Prieto, R. Garcia-Gozalez, S. Andrs, F. J. Giraldez, and S. Lopez, "Manipulation of rumen fermentation and methane production with plant secondary metabolites," Animal Feed Science and Technology, vol. 176, no. 1-4, pp. 78-93, 2012.

[12] A. K. Patra and J. Saxena, "Dietary phytochemicals as rumen modifiers: a review of the effects on microbial populations," Antonie van Leeuwenhoek, vol. 96, no. 4, pp. 363-375, 2009.

[13] W. Hu, J. Liu, J. Ye, Y. Wu, and Y. Guo, "Effect of tea saponin on rumen fermentation in vitro," Animal Feed Science and Technology, vol. 120, no. 3-4, pp. 333-339, 2005.

[14] G. Goel, H. P. S. Makkar, and K. Becker, "Changes in microbial community structure, methanogenesis and rumen fermentation in response to saponin-rich fractions from different plant materials," Journal of Applied Microbiology, vol. 105, no. 3, pp. 770-777, 2008.

[15] A. K. Patra and J. Saxena, "The effect and mode of action of saponins on the microbial populations and fermentation in the rumen and ruminant production," Nutrition Research Reviews, vol. 22, no. 2, pp. 204-219, 2009.
[16] B. C. Pal, B. Achari, K. Yoshikawa, and S. Arihara, "Saponins from Albizia lebbeck," Phytochemistry, vol. 38, no. 5, pp. 12871291, 1995.

[17] S. Hiai, H. Oura, and T. Nakajima, "Color reaction of some sapogenins and saponins with vanillin and sulfuric acid," Planta Medica, vol. 29, no. 2, pp. 116-122, 1976.

[18] I. L. Shiau, T. L. Shih, Y. N. Wang et al., "Quantification for saponin from a soapberry in cleaning products by a chromatographic and two colorimetric assays," Journal of the Faculty of Agriculture Kyushu University, vol. 54, pp. 215-221, 2009.

[19] A. W. Bauer, W. M. Kirby, J. C. Sherris, and M. Turck, "Antibiotic susceptibility testing by a standardized single disk method," American Journal of Clinical Pathology, vol. 45, no. 4, pp. 493496, 1966.

[20] K. H. Menke and H. Steingass, "Estimation of the energetic feed value obtained from chemical analysis and in vitro gas production using rumen fluid," Animal Research and Development, vol. 28, pp. 7-55, 1988.

[21] P. J. van Soest, "Development of a comprehensive system of feed analysis and its application to forages," Journal of Animal Science, vol. 26, pp. 119-128, 1967.

[22] AOAC, Official Methods of Analysis of AOAC International, AOAC International, Gaithersburg, Md, USA, 18th edition, 2005.

[23] P. J. van Soest, J. B. Robertson, and B. A. Lewis, "Methods for dietary fiber, neutral detergent fiber, and nonstarch polysaccharides in relation to animal nutrition," Journal of Dairy Science, vol. 74, no. 10, pp. 3583-3597, 1991.

[24] E. S. Erwin, G. A. Macro, and E. M. Emery, "Volatile fatty acid analysis of blood and rumen fluid by gas chromatograph," Journal of Dairy Science, vol. 44, no. 9, pp. 1768-1771, 1961.

[25] M. Blümmel, H. P. S. Makkar, and K. Becker, "In vitro gas production: a technique revisited," Journal of Animal Physiology and Animal Nutrition, vol. 77, no. 1, pp. 24-34, 1997.

[26] E. R. Ørskov and I. McDonald, "The estimation of protein degradability in the rumen from incubation measurements weighted according to rate of passage," The Journal of Agricultural Science, vol. 92, no. 2, pp. 499-503, 1979.

[27] G. W. Snedecor and W. G. Cochran, Statistical Methods, Iowa State University Press, Ames, Iowa, USA, 5th edition, 1968.

[28] O. P. Sheoran, "Online Statistical Analysis (OPSTAT)," 2010, developed by CCS Haryana Agricultural University, Hissar, Haryana, India http://www.hau.ernet.in/opstat.html.

[29] W. B. Hugo and A. D. Russell, Pharmaceutical Microbiology, W. B. Hugo, A. D. Russell, Ed., pp, 33-35, 51, Blackwell Scientific Publications, 3rd edition, 1983.

[30] L. L. Zaika, "Spices and herbs: their antimicrobial activity and its determination," Journal of Food Safety, vol. 9, no. 2, pp. 97-118, 1988.

[31] K. O. Soetan, M. A. Oyekunle, O. O. Aiyelaagbe, and M. A. Fafunso, "Evaluation of the antimicrobial activity of saponins extract of Sorghum Bicolor L. Moench," African Journal of Biotechnology, vol. 5, no. 23, pp. 2405-2407, 2006.

[32] V. Irudayaraj, J. M, M. Johnson, and N. Selvan, "Preliminary phytochemical and antimicrobial studies on a spike-moss Selaginella inaequalifolia (Hook. \& Grev.) Spring," Asian Pacific Journal of Tropical Medicine, vol. 3, no. 12, pp. 957-960, 2010.

[33] J. B. Campbell, Saponins: Adjuvants: Theory and Practical Applications, D. E. S. Stewart-Tull, Ed., chapter 4, ButterworthHeinemann, London, UK, 1993. 
[34] P. Mandal, S. P. Sinha, and N. C. Mandal, "Antimicrobial activity of saponins from Acacia auriculiformis," Fitoterapia, vol. 76, no. 5, pp. 462-465, 2005.

[35] P. Avato, R. Bucci, A. Tava et al., "Antimicrobial activity of saponins from Medicago sp.: structure-activity relationship," Phytotherapy Research, vol. 20, no. 6, pp. 454-457, 2006.

[36] Y. Wang, D. Gibb, D. Greer, and T. A. McAllister, "Effects of moisture and a saponin-based surfactant during barley processing on growth performance and carcass quality of feedlot steers and on in vitro ruminal fermentation," Asian-Australasian Journal of Animal Sciences, vol. 24, no. 12, pp. 1690-1698, 2011.

[37] A. Bharathidhasan, K. Viswanathan, V. Balakrishnan, C. Valli, S. Ramesh, and S. M. A. Senthilkumar, "Effects of purified saponin on rumen methanogenesis and rumen fermentation characteristics studied using in vitro gas production technique," International Journal Veterinary Science, vol. 2, no. 2, pp. 44-49, 2013.

[38] N. Goel, S. K. Sirohi, and J. Dwivedi, "Estimation of total saponins and evaluate their effect on in vitro methanogenesis and rumen fermentation pattern in wheat straw based diet," Journal of Advanced Veterinary Research, vol. 2, no. 2, pp. 120126, 2012.

[39] Z. A. Lila, N. Mohammed, S. Kanda, T. Kamada, and H. Itabashi, "Effect of sarsaponin on ruminal fermentation with particular reference to methane production in vitro," Journal of Dairy Science, vol. 86, no. 10, pp. 3330-3336, 2003.

[40] N. Agarwal, D. N. Kamra, L. C. Chaudhary, and A. K. Patra, "Effect of Sapindus mukorossi extracts on in vitro methanogenesis and fermentation characteristics in buffalo rumen liquor," Journal of Applied Animal Research, vol. 30, no. 1, pp. 1-4, 2006.

[41] Y. Q. Guo, J.-X. Liu, Y. Lu, W. Y. Zhu, S. E. Denman, and C. S. McSweeney, "Effect of tea saponin on methanogenesis, microbial community structure and expression of mcrA gene, in cultures of rumen micro-organisms," Letters in Applied Microbiology, vol. 47, no. 5, pp. 421-426, 2008.

[42] L. Holtshausen, A. V. Chaves, K. A. Beauchemin et al., "Feeding saponin-containing Yucca schidigera and Quillaja saponaria to decrease enteric methane production in dairy cows," Journal of Dairy Science, vol. 92, no. 6, pp. 2809-2821, 2009.

[43] Z. H. Feng, Y. F. CaO, Y. X. Gao, Q. F. Li, and J. G. Li, "Effects of gross saponin of Tribulus terrestris on ruminal fermentation and methane production in vitro," Journal of Animal and Veterinary Advanced, vol. 11, no. 12, pp. 2125-2125, 2012.

[44] J. M. Castro-Montoya, H. P. S. Makkar, and K. Becker, "Chemical composition of rumen microbial fraction and fermentation parameters as affected by tannins and saponins using an in vitro rumen fermentation system," Canadian Journal of Animal Science, vol. 91, no. 3, pp. 433-448, 2011.

[45] A. Machmüller, C. R. Soliva, and M. Kreuzer, "Effect of coconut oil and defaunation treatment on methanogenesis in sheep," Reproduction Nutrition Development, vol. 43, no. 1, pp. 41-55, 2003.

[46] H. P. S. Makkar and K. Backer, "Effect of Quillaja saponins on in vitro rumen fermentation," Advances in Experimental Medicine and Biology, vol. 405, pp. 387-394, 1996.

[47] L. Istiqomah, H. Herdian, A. Febrisantosa, and D. Putra, "Waru leaf (Hibiscus tillaceus) as saponin source on in vitro ruminal fermentation characteristic," Journal of the Indonesian Tropical Animal Agriculture, vol. 36, no. 1, pp. 43-49, 2011.

[48] A. G. Williams and G. S. Coleman, The Rumen Protozoa, Springer, New York, NY, USA, 1991.
[49] A. N. Hristov, T. A. McAllister, F. H. van Herk, K.-J. Cheng, C. J. Newbold, and P. R. Cheeke, "Effect of Yucca schidigera on ruminal fermentation and nutrient digestion in heifers," Journal of Animal Science, vol. 77, no. 9, pp. 2554-2563, 1999.

[50] H. D. Hess, M. Kreuzer, T. E. Díaz et al., "Saponin rich tropical fruits affect fermentation and methanogenesis in faunated and defaunated rumen fluid," Animal Feed Science and Technology, vol. 109, no. 1-4, pp. 79-94, 2003.

[51] G. Francis, Z. Kerem, H. P. S. Makkar, and K. Becker, "The biological action of saponins in animal systems: a review," British Journal of Nutrition, vol. 88, no. 6, pp. 587-605, 2002. 

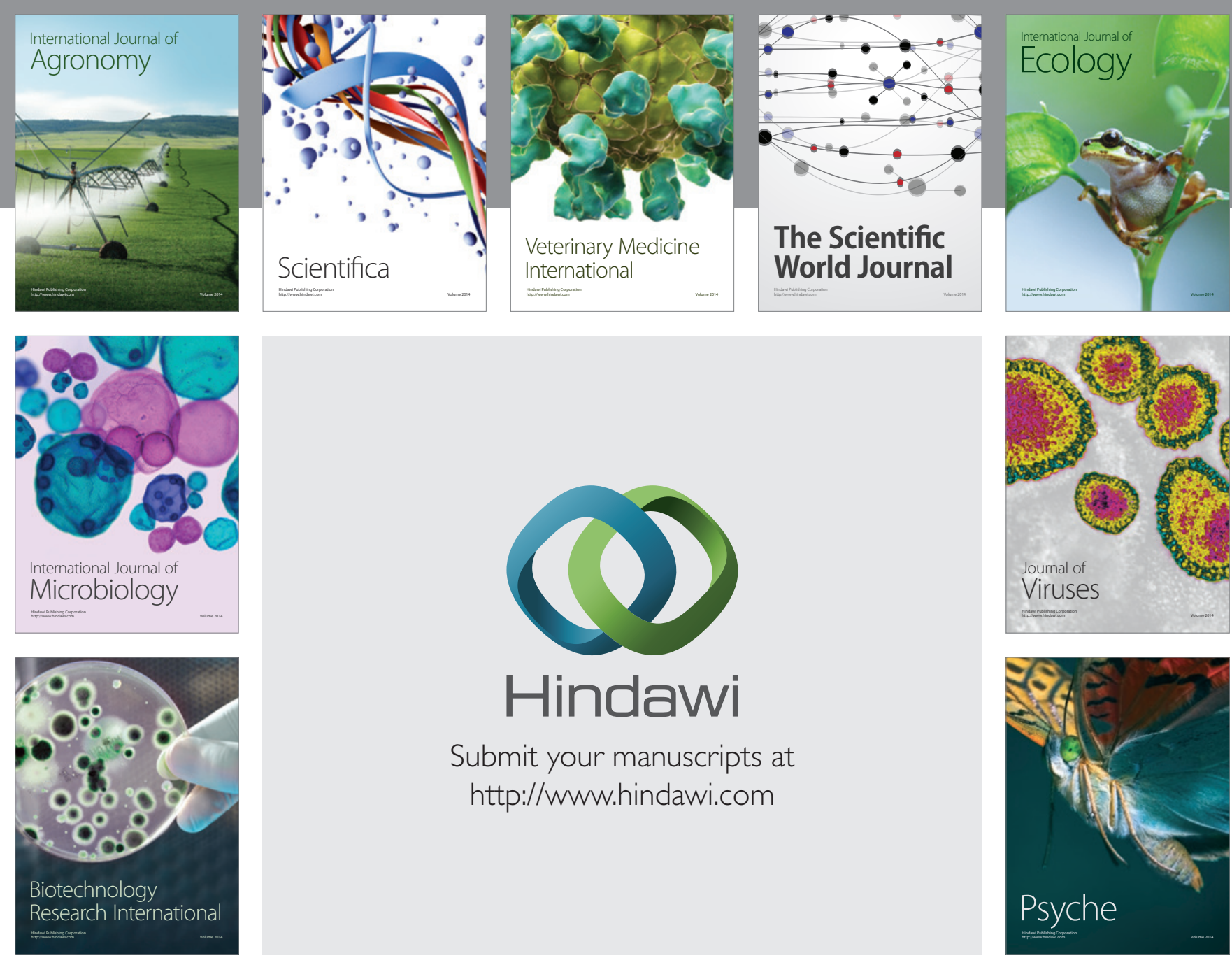

Submit your manuscripts at http://www.hindawi.com
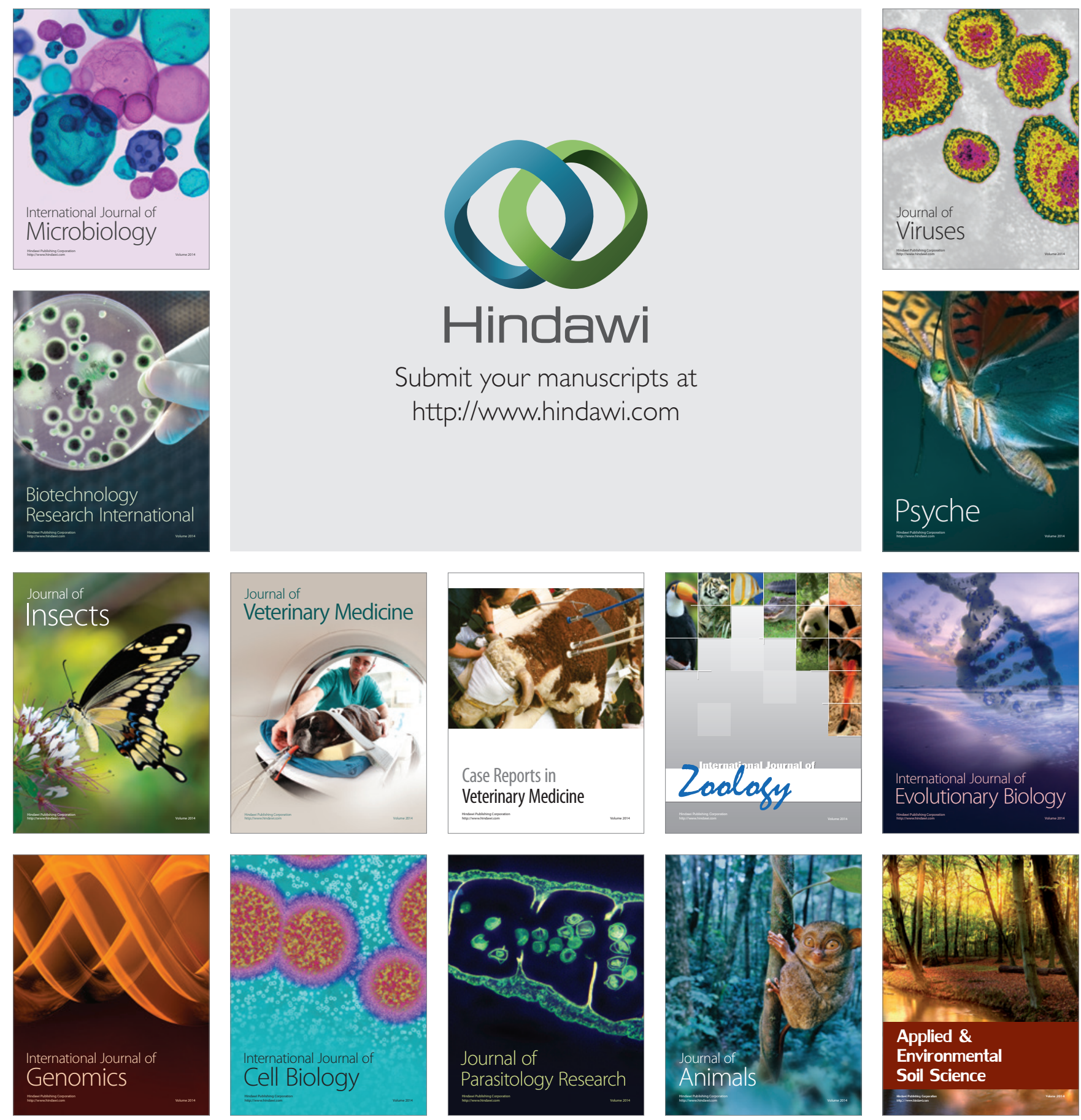